\title{
SCIDOC
}

Infer, Interpret \& Inspire Science

International Journal of Dentistry and Oral Science (IJDOS) ISSN: $2377-8075$

\section{Prevalence Herpes Labialis among South Indian Population: an Institutional Study}

Research Article

Jembulingam Sabarathinam ${ }^{1}$, Manjari Chaudhary ${ }^{2 *}$, Madhulaxmi $\mathrm{M}^{3}$

${ }^{1}$ Saveetha Dental College and Hospitals, Saveetha Institute of Medical and Technical Sciences(SIMATS), Saveetha University, Chennai 600077, Tamil Nadu, India.

${ }^{2}$ Senior Lecturer, Department of Oral Medicine and Radiology, Saveetha Dental College and Hospital, Saveetha Institute of Medical and Technical Sciences(SIMATS), Saveetha University, Chennai 600077, Tamil Nadu, India.

${ }^{3}$ Professor, Department of Oral and Maxillofacial Surgery, Saveetha Dental College and Hospital, Saveetha Institute of Medical and Technical Sciences(SIMATS), Saveetha University, Chennai 600077, Tamil Nadu, India.

\section{Abstract}

Herpes labialis is the most commonly occurring infection in the orofacial region in the form of cold sores and fever blisters. Most of the patients often have episodes of relapse. Herpes labialis is often characterised by a common set of symptoms which includes rashes over the lips areas, erythematous blisters and burning pain. Herpes labialis is caused by herpes simplex-1 virus while rarely caused by herpes simplex 2 virus. The diagnosis of herpes labialis is often limited to taking patients history and performing physical examinations. A primary infection is often characterised by small clusters of blisters or ulcers $(2 \mathrm{~mm}$ to $10 \mathrm{~mm}$ ) in front of the lip, tongue, mouth characterised by presence of fever. This study was aimed to assess the prevalence of herpes labialis and its association with age among the patients reporting to a private institutional set up in Chennai. The study was conducted among 44,000 patients attending the outpatient department of a private institution in chennai during a time period of 6 months between June 2019 to December 2019. The patient records were assessed and tabulated in MS-Excel. The data was analysed by SPSS software and the results were interpreted. The prevalence of herpes labialis was $0.14 \%$ among the study population attending the outpatient department of a private institution. Male predilection was observed. Within the limitations of our current study, it is concluded that there is a reduced prevalence of herpes labialis in the study population.

Keywords: Gender Predilection; Herpes Labialis; Prevalence; South Indian.

\section{Introduction}

Herpes labialis is the most commonly occurring infection in the orofacial region in the form of cold sores and fever blisters [1]. Most of the patients often have episodes of relapse [2]. Herpes labialis is often characterised by a common set of symptoms which includes rashes over the lips areas, erythematous blisters and burning pain. Herpes labialis is a contagious disease even though it heals within 10 days, it can still spread to a person who is still not immune to the disease [3] nor being infected before the recent infection unlike other white and red lesions of the oral cavity, carcinoma and pericoronitis [4-13]. In addition, Herpes labialis through orogenital contact can lead to genital herpes [14].

Herpes labialis is caused by herpes simplex-1 virus while rarely caused by herpes simplex 2 virus [15]. The primary infection most commonly occurs before the second decade of life, while $80 \%$ of the antibodies can be found in the adolescents probably due to increasing socioeconomic status. Recently there has been an increased prevalence of herpes labialis caused by genital ulcers. $[14,16,17]$.

The virus remains latent in the ganglion of the sensory nerves, where stimulus such as sunlight, menstruation, fever and respiratory infection reactivates [18] the virus which affects the mucosa of the hard palate and lips only [19] in contrast to the primary infection. The number of relapses rapidly decreases above 35 years of age [20].

The diagnosis of herpes labialis is often limited to taking patients history and performing physical examinations. A primary infection is often asymptomatic while when symptoms occur, it most commonly includes small clusters of blisters or ulcers $(2 \mathrm{~mm}$ to $10 \mathrm{~mm}$ ) in front of the lip, tongue, mouth characterised by pres-

*Corresponding Author:

Dr Manjari Chaudhary,

Senior Lecturer, Department of Oral Medicine and Radiology, Saveetha Dental College and Hospital, Saveetha Institute of Medical and Technical Sciences(SIMATS), Saveetha University, 162, PH Road, Chennai 600077, Tamil Nadu, India. Tel: +917044455554

E-mail: manjaric.sdc@saveetha.com

Received: July 30, 2021

Accepted: August 11, 2021

Published: August 19, 2021

Citation: Jembulingam Sabarathinam, Manjari Chaudhary, Madhulaxmi M. Prevalence Herpes Labialis among South Indian Population: an Institutional Study. Int J Dentistry Oral Sci. 2021;8(8):4036-4039. doi: http://dx.doi.org/10.19070/2377-8075-21000824

Copyright: Dr Manjari Chaudhary 2021 . This is an open-access article distributed under the terms of the Creative Commons Attribution License, which permits unrestricted use, distribution and reproduction in any medium, provided the original author and source are credited. 
ence of fever [21].

The occurrence of relapse is often characterised by burning skin rashes around the mouth which manifest as papules, macules, crusts and vesicles. Many of the dental surgeons miss diagnose herpes labialis which could pave the way for surgeons to get infected without precautions.

Henceforth the current study aims to assess the prevalence of herpes labialis and its gender association among the patients reporting to an institutional set up in Chennai, TamilNadu which is a tertiary health center with advanced diagnostic aids [22-26]. Previously our team has a rich experience in working on various research projects across multiple disciplines [27-41]. Now the growing trend in this area motivated us to pursue this project.

\section{Materials and Methods}

This study was performed in a private institution in Chennai, among the outpatients during a time period of 6 months from June 2019 to December 2019. The total sample size was 44,000. Patient records were assessed and interpreted for the number of people who were diagnosed with herpes labialis in a private institution in chennai. Incomplete data without diagnostic notes and photographs were excluded from the study.

Institutional ethical committee clearance was obtained for data retrieval and usage as needed for the study (SDC/SIHEC/2020/ DIASDATA/0619-0320). The verification of the details was done with the presence of two reviewers to reduce observer's bias. The verification process was done with the help of diagnostic notes and Photographs. The data obtained was tabulated in MS-Excel software with parameters which include age, gender, presence of herpes labialis and etiology. The data was interpreted using IBM SPSS (version 20) and the results were tabulated and interpreted.

\section{Results \& Discussion}

The prevalence of Herpes labialis in our current study was $0.14 \%$ where 44,000 individuals participated during the time period of 6 months from June 2019- December 2019.

Among the patients diagnosed with herpes labialis, patients were aged between 6-66 years with a mean age of 41 years. (Figure 1).There was a male predilection (53\%) while females had $47 \%$ (Figure 2).

There was no association between the age groups and gender in patients with herpes labialis. There was no statistical significance ( $p-0.996)$ ( $p$ value $>0.05$ ) (Figure 3). This could be due to the unequal distribution of cases among various age groups.

The prevalence of herpes labialis in our current study was $0.14 \%$ over a period of 5 months, which consisted of patients aged between 6 years to 66 years with the mean age of 41 years affected by the disease. There was a male predilection which was not statistically significant. There was no correlation between age and gender to the prevalence of herpes labialis.

Figure 1: Bar graph depicts the percentage of patients diagnosed with herpes labialis among various age groups; where $Y$ axis shows the percentage of patients diagnosed with herpes labialis and $\mathrm{X}$ axis shows the various age groups. Majority of the patients diagnosed with herpes labialis are between the age 20-50 years (Red) when compared to other age groups such as below 20 years (Orange) and above 50 years (Yellow).

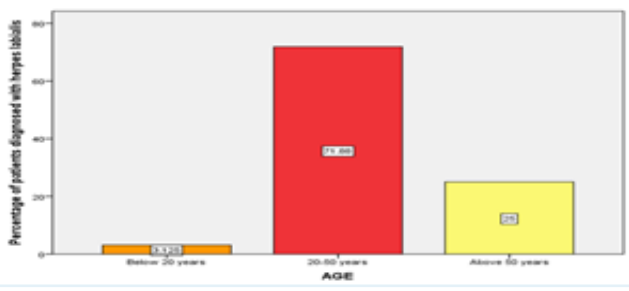

Figure 2: Bar graph depicts the percentage of males and females diagnosed with herpes labialis; where $\mathrm{Y}$ axis shows the percentage of patients diagnosed with herpetic ulcer and $\mathrm{X}$ axis shows the gender of patients. Males (Blue) experienced a slight increase in frequency of herpes labialis in comparison to females (Green).

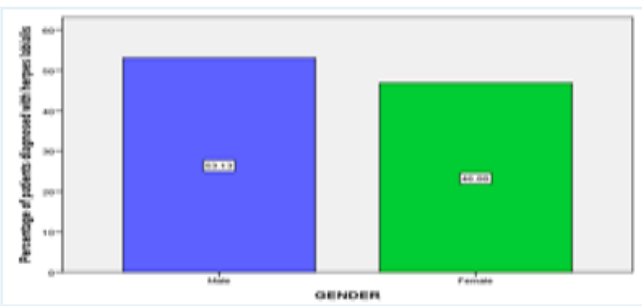

Figure 3: Bar graph depicts association between the age group and gender; where Y axis shows the percentage of patients diagnosed with herpes labialis and $\mathrm{X}$ axis shows the various age groups. Chi square test was done and association was found to be statistically not significant ; Pearson's value:0.009, DF:2, p value: $0.996(>0.05)$. Even though the majority of patients diagnosed with herpes labialis was under the age group $20-50$ years among which males (Blue) experienced higher prevalence than females (Green) in comparison to other age groups.

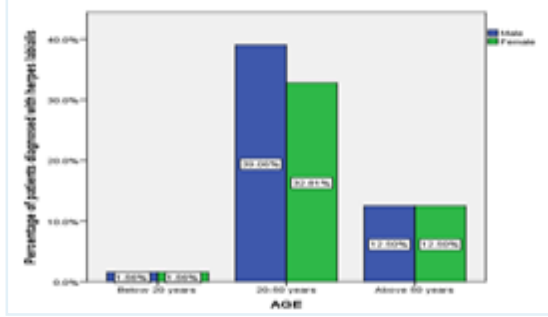


Van der Linden MW et al., [1] reported that the prevalence of herpes labialis was $2.5 \%$ among the Netherland population when the Netherland institute of public health and institute of environment undertook a study. 1.6 per 1000 patients were diagnosed with herpes labialis. The results of our current study contradicts the previous study as there was an increased prevalence of herpes labialis. The variations of the results could be due to geographically isolated population, short term analysis of the current study.

Graham worrall et al., [42] in the BMJ clinical evidence journal suggested that the prevalence of herpes labialis was $1 \%$ among the population of the United kingdom with no gender predilection. The results of our current study is in favour of the previous study in relation to the gender predilection but contradicts with a 10 fold increase in the prevalence.

Jun A et al., [2] reported that out of 10532 patients participating in the study among 21 different countries and 43 institutions, the prevalence of herpes labialis was $15 \%$ approximately with a mild male prediction (33\%). He also reported that there is significant difference in the presence of ulcers and profession. This implicates that increase in stress, increases the occurrence or prevalence of the ulcers. The present study is in contradiction with the previous study due to increased prevalence of herpes labialis while in agreement with the gender predilection of the previous studies.

Jenifer kula et al., [43] in 2015 suggested that the prevalence of herpes labialis in 402 individuals consisting of mainly high concentration of women was $28 \%$, while most of the lesions were associated with stress and lowered immunity. Above mentioned study contradicts the results of our current study where the prevalence is only $0.14 \%$.

Amadori et al., [44] reported that there was a prevalence of $11 \%$ of herpes labialis among 170 teenagers in the Italian population which was statistically not significant and also reported that systemic diseases do not have any association with herpes labialis or HSV infections. The previous literature contradicts the results of our current study.

Ali riza et al., [45] reported that there is a $2 \%$ prevalence of herpes labialis among the Turkish population with a female predilection $(68 \%)$ which contradicts our present study which has reduced the prevalence and had no gender predilection. This might be due to the reduced population or sample size of the previous study which had only 5000 samples. Our institution is passionate about high quality evidence based research and has excelled in various fields [46-56]. We hope this study adds to this rich legacy.

\section{Conclusion}

The present study can be concluded that there was male gender predilection towards prevalence of herpes labialis which occurs in ages and predominantly affects the population during the first four decades of life. There was a decreased prevalence of herpes labialis indicating that the population of south India did not seek professional help for the treatment of herpes labialis, which implicates that knowledge and awareness of herpes labialis was less among the study population and more awareness need to be brought about by medical camps amongst the population in order to curb the disease and limit its spread.

\section{References}

[1]. Westert GP, Schellevis FG, De Bakker DH, Groenewegen PP, Bensing JM, Van der Zee J. Monitoring health inequalities through general practice: the Second Dutch National Survey of General Practice. Eur J Public Health. 2005 Feb 1;15(1):59-65.

[2]. Embil JA, Stephens RG, Manuel FR. Prevalence of recurrent herpes labialis and aphthous ulcers among young adults on six continents. Can Med Assoc J. 1975 Oct 4;113(7):627-30.Pubmed PMID: 1181018.

[3]. Sparano JA, Sarta C. Infection prophylaxis and antiretroviral therapy in patients with HIV infection and malignancy. Curr Opin Oncol. 1996 Sep 1;8(5):392-9.

[4]. Venugopal A, Uma Maheswari TN. Expression of matrix metalloproteinase-9 in oral potentially malignant disorders: A systematic review. J Oral Maxillofac Pathol. 2016 Sep-Dec;20(3):474-479.Pubmed PMID: 27721614.

[5]. Chaitanya NC, Muthukrishnan A, Babu DBG, Kumari CS, Lakshmi MA, Palat G, et al. Role of Vitamin E and Vitamin A in Oral Mucositis Induced by Cancer Chemo/Radiotherapy- A Meta-analysis. J Clin Diagn Res. 2017 May;11(5):ZE06-ZE09.Pubmed PMID: 28658926.

[6]. Subashri A, Maheshwari TN. Knowledge and attitude of oral hygiene practice among dental students. Res J Pharm Technol. 2016;9(11):1840-2.

[7]. Maheswari TNU, Venugopal A, Sureshbabu NM, Ramani P. Salivary micro RNA as a potential biomarker in oral potentially malignant disorders: A systematic review. Ci Ji Yi Xue Za Zhi. 2018 Apr-Jun;30(2):55-60.Pubmed PMID: 29875583.

[8]. Misra SR, Shankar YU, Rastogi V, Maragathavalli G. Metastatic hepatocellular carcinoma in the maxilla and mandible, an extremely rare presentation. Contemp. Clin. Dent. 2015 Mar;6(Suppl 1):S117.

[9]. Steele JC, Clark HJ, Hong CH, Jurge S, Muthukrishnan A, Kerr AR, et al. World Workshop on Oral Medicine VI: an international validation study of clinical competencies for advanced training in oral medicine. Oral Surg Oral Med Oral Pathol Oral Radiol. 2015 Aug;120(2):143-51.e7.Pubmed PMID: 25861956

[10]. Muthukrishnan A, Warnakulasuriya S. Oral health consequences of smokeless tobacco use. Indian J Med Res. 2018 Jul;148(1):35-40.

[11]. Patil SR, Maragathavalli G, Araki K, Al-Zoubi IA, Sghaireen MG, Gudipaneni RK, et al. Three-rooted mandibular first molars in a Saudi Arabian population: A CBCT study. Pesqui Bras Odontopediatria Clin Integr . 2018 Aug 27;18(1):e4133.

[12]. Chaitanya NC, Muthukrishnan A, Krishnaprasad CMS, Sanjuprasanna G, Pillay P, Mounika B. An Insight and Update on the Analgesic Properties of Vitamin C. J Pharm Bioallied Sci. 2018 Jul-Sep;10(3):119-125.Pubmed PMID: 30237682.

[13]. Rohini S, Kumar VJ. Incidence of dental caries and pericoronitis associated with impacted mandibular third molar-A radiographic study. Res J Pharm Technol. 2017;10(4):1081-4.

[14]. Scoular A, Norrie J, Gillespie G, Mir N, Carman WF. Longitudinal study of genital infection by herpes simplex virus type 1 in Western Scotland over 15 years. BMJ. 2002 Jun 8;324(7350):1366-7.Pubmed PMID: 12052804.

[15]. Lafferty WE, Coombs RW, Benedetti J, Critchlow C, Corey L. Recurrences after oral and genital herpes simplex virus infection. N Engl J Med. 1987 Jun 4;316(23):1444-9.

[16]. Corey L, Handsfield HH. Genital herpes and public health: addressing a global problem. Jama. 2000 Feb 9;283(6):791-4.

[17]. Ross JD, Smith IW, Elton RA. The epidemiology of herpes simplex types 1 and 2 infection of the genital tract in Edinburgh 1978-1991. Genitourin Med. 1993 Oct;69(5):381-3.Pubmed PMID: 8244358.

[18]. Wheeler Jr CE. The herpes simplex problem. J Am Acad Dermatol. 1988 Jan 1;18(1):163-8.

[19]. Esmann J. The many challenges of facial herpes simplex virus infection. J. Antimicrob. Chemother. 2001 Feb 1;47(suppl_1):17-27.

[20]. STRAUS SE, ROONEY JF, SEVER JL, SEIDLIN M, NUSINOFF-LEHRMAN SA, CREMER K. Herpes simplex virus infection: biology, treatment, and prevention. Ann. Intern. Med. 1985 Sep 1;103(3):404-19.

[21]. Arnold Flat share. U. Checklist ear, nose and throat medicine.2005.

[22]. Dharman S, Muthukrishnan A. Oral mucous membrane pemphigoid - Two case reports with varied clinical presentation. J Indian Soc Periodontol. 2016 Nov-Dec;20(6):630-634.Pubmed PMID: 29238145.

[23]. Subha M, Arvind M. Role of magnetic resonance imaging in evaluation of trigeminal neuralgia with its anatomical correlation. Biomed. pharmacol. J. 2019 Mar 25;12(1):289-96.

[24]. Muthukrishnan A, Kumar LB. Actinic cheilosis: early intervention prevents malignant transformation [Internet]. BMJ Case Rep. 2017: bcr2016218654. 
[25]. Choudhury P, Panigrahi RG, Maragathavalli, Panigrahi A, Patra PC. Vanishing roots: first case report of idiopathic multiple cervico-apical external root resorption. J Clin Diagn Res. 2015 Mar;9(3):ZD17-9.Pubmed PMID: 25954713

[26]. Muthukrishnan A, Bijai Kumar L, Ramalingam G. Medication-related osteonecrosis of the jaw: a dentist's nightmare. BMJ Case Rep. $2016 \mathrm{Apr}$ 6;2016:bcr2016214626.Pubmed PMID: 27053542.

[27]. Jain AR. Prevalence of partial edentulousness and treatment needs in rural population of South India. World J Dent. 2017 Jun;8(3):213-7.

[28]. Varghese SS, Ramesh A, Veeraiyan DN. Blended Module-Based Teaching in Biostatistics and Research Methodology: A Retrospective Study with Postgraduate Dental Students. J Dent Educ. 2019 Apr;83(4):445-450.Pubmed PMID: 30745352

[29]. Ashok V, Ganapathy D. A geometrical method to classify face forms. J Oral Biol Craniofac Res. 2019 Jul 1;9(3):232-5.

[30]. Padavala S, Sukumaran G. Molar incisor hypomineralization and its prevalence. Contemp Clin Dent. 2018 Sep;9(Suppl 2):S246-50.

[31]. Ke Y, Al Aboody MS, Alturaiki W, Alsagaby SA, Alfaiz FA, Veeraraghavan VP, et al. Photosynthesized gold nanoparticles from Catharanthus roseus induces caspase-mediated apoptosis in cervical cancer cells (HeLa). Artif Cells Nanomed Biotechnol. 2019 Dec;47(1):1938-1946.Pubmed PMID: 31099261 .

[32]. Ezhilarasan D. Oxidative stress is bane in chronic liver diseases: Clinical and experimental perspective. Arab J Gastroenterol. 2018 Jun;19(2):56-64.Pubmed PMID: 29853428

[33]. Krishnan RP, Ramani P, Sherlin HJ, Sukumaran G, Ramasubramanian A, Jayaraj G, et al. Surgical Specimen Handover from Operation Theater to Laboratory: A Survey. Ann Maxillofac Surg. 2018 Jul-Dec;8(2):234-238. Pubmed PMID: 30693238

[34]. Ezhilarasan D, Sokal E, Najimi M. Hepatic fibrosis: It is time to go with hepatic stellate cell-specific therapeutic targets. Hepatobiliary Pancreat Dis Int. 2018 Jun;17(3):192-197.Pubmed PMID: 29709350

[35]. Pandian KS, Krishnan S, Kumar SA. Angular photogrammetric analysis of the soft-tissue facial profile of Indian adults. Indian J Dent Res. 2018 Mar $1 ; 29(2): 137-43$.

[36]. Ramamurthy JA, Mg V. Comparison of effect of Hiora mouthwash versus Chlorhexidine mouthwash in gingivitis patients: A clinical trial. Asian J Pharm Clin Res. 2018 Jul 7;11(7):84-8.

[37]. Gupta P, Ariga P, Deogade SC. Effect of Monopoly-coating Agent on the Surface Roughness of a Tissue Conditioner Subjected to Cleansing and Disinfection: A Contact Profilometric In vitro Study. Contemp Clin Dent. 2018 Jun;9(Suppl 1):S122-S126.Pubmed PMID: 29962776.

[38]. Vikram NR, Prabhakar R, Kumar SA, Karthikeyan MK, Saravanan R. Ball Headed Mini Implant. J Clin Diagn Res. 2017 Jan;11(1):ZL02-3.

[39]. Paramasivam A, Vijayashree Priyadharsini J, Raghunandhakumar S. N6adenosine methylation (m6A): a promising new molecular target in hypertension and cardiovascular diseases. Hypertens Res. 2020 Feb;43(2):153154.Pubmed PMID: 31578458

[40]. Palati S, Ramani P, Shrelin HJ, Sukumaran G, Ramasubramanian A, Don $\mathrm{KR}$, et al. Knowledge, Attitude and practice survey on the perspective of oral lesions and dental health in geriatric patients residing in old age homes. Indian J Dent Res. 2020 Jan-Feb;31(1):22-25.Pubmed PMID: 32246676.

[41]. Samuel SR, Acharya S, Rao JC. School Interventions-based Prevention of Early-Childhood Caries among 3-5-year-old children from very low socioeconomic status: Two-year randomized trial. J Public Health Dent. 2020
Jan;80(1):51-60.Pubmed PMID: 31710096.

[42]. Worrall G. Herpes labialis. BMJ Clin Evid. 2009;2009.

[43]. KULA J, HENN IW, PENZO FE, GOETTEMS JJ, MIRANDA MS, FERNANDES Â, et al. Recurrent Herpes Labialis: Epidemiological, Clinical, and Therapeutic Aspects. Oral Surg Oral Med Oral Pathol Oral Radiol. 2015 Aug 1;120(2):e96.

[44]. Amadori F, Bardellini E, Conti G, Majorana A. Oral mucosal lesions in teenagers: a cross-sectional study. Ital. J. Pediatr. 2017 Dec;43(1):1-6.

[45]. Cebeci AR, Gülşahi A, Kamburoglu K, Orhan BK, Oztaş B. Prevalence and distribution of oral mucosal lesions in an adult Turkish population. Med Oral Patol Oral Cir Bucal. 2009 Jun 1;14(6):E272-7.Pubmed PMID: 19300376.

[46]. Vijayashree Priyadharsini J. In silico validation of the non-antibiotic drugs acetaminophen and ibuprofen as antibacterial agents against red complex pathogens. J Periodontol. 2019 Dec;90(12):1441-1448.Pubmed PMID: 31257588.

[47]. Pc J, Marimuthu T, Devadoss P, Kumar SM. Prevalence and measurement of anterior loop of the mandibular canal using CBCT: A cross sectional study Clin Implant Dent Relat Res. 2018 Apr 6;20(4):531-4.

[48]. Ramesh A, Varghese S, Jayakumar ND, Malaiappan S. Comparative estimation of sulfiredoxin levels between chronic periodontitis and healthy patients - A case-control study. J Periodontol. 2018 Oct;89(10):1241-1248.Pubmed PMID: 30044495.

[49]. Ramadurai N, Gurunathan D, Samuel AV, Subramanian E, Rodrigues SJ. Effectiveness of $2 \%$ Articaine as an anesthetic agent in children: randomized controlled trial. Clin. Oral Investig. 2019 Sep;23(9):3543-50.

[50]. Sridharan G, Ramani P, Patankar S, Vijayaraghavan R. Evaluation of salivary metabolomics in oral leukoplakia and oral squamous cell carcinoma. J Oral Pathol Med. 2019 Apr;48(4):299-306.

[51]. Ezhilarasan D, Apoorva VS, Ashok Vardhan N. Syzygium cumini extract induced reactive oxygen species-mediated apoptosis in human oral squamous carcinoma cells. J Oral Pathol Med. 2019 Feb;48(2):115-121.Pubmed PMID: 30451321

[52]. Mathew MG, Samuel SR, Soni AJ, Roopa KB. Evaluation of adhesion of Streptococcus mutans, plaque accumulation on zirconia and stainless steel crowns, and surrounding gingival inflammation in primary molars: randomized controlled trial. Clin Oral Investig. 2020 Sep;24(9):1-6.Pubmed PMID: 31955271

[53]. Samuel SR. Can 5-year-olds sensibly self-report the impact of developmental enamel defects on their quality of life? Int J Paediatr Dent. 2021 Mar;31(2):285-286.Pubmed PMID: 32416620.

[54]. R H, Ramani P, Ramanathan A, R JM, S G, Ramasubramanian A, et al. CYP2 C9 polymorphism among patients with oral squamous cell carcinoma and its role in altering the metabolism of benzo[a]pyrene. Oral Surg Oral Med Oral Pathol Oral Radiol. 2020 Sep;130(3):306-312.Pubmed PMID: 32773350.

[55]. Chandrasekar R, Chandrasekhar S, Sundari KKS, Ravi P. Development and validation of a formula for objective assessment of cervical vertebral bone age. Prog Orthod. 2020 Oct 12;21(1):38.Pubmed PMID: 33043408.

[56]. Vijayashree Priyadharsini J, Smiline Girija AS, Paramasivam A. In silico analysis of virulence genes in an emerging dental pathogen A. baumannii and related species. Arch Oral Biol. 2018 Oct;94:93-98.Pubmed PMID: 30015217. 